\title{
Persistence of water repellency in coarse-textured soils under various types of forests in NW Spain
}

\author{
Elena Benito*, Eufemia Varela, María Rodríguez-Alleres \\ Departamento de Biología Vegetal y Ciencia del Suelo, Universidad de Vigo, 36310 Vigo, Spain. \\ *Corresponding author. Tel.: +34986812396. E-mail: rueda@uvigo.es
}

\begin{abstract}
The primary purpose of this work was to assess the persistence of water repellency in the surface horizon of coarse-textured soils under natural Quercus robur ecosystems, and Pinus pinaster and Eucalyptus globulus plantations, in the northwest of the Iberian Peninsula. Water repellency was determined by applying the water drop penetration test (WDPT) to soil samples collected from variable depths $(0-40 \mathrm{~cm})$. Measurements were made on field-moist samples obtained at the end of the dry period and on samples dried at $25^{\circ} \mathrm{C}$ in the air. All soils exhibited very high (severe to extreme) water repellency in the topmost soil layer $(0-5 \mathrm{~cm})$ but no significant differences among the three plant species studied. Extreme persistence was observed down to $20 \mathrm{~cm}$ in the soils under eucalyptus and down to $10 \mathrm{~cm}$ in those under pine. The soils under oak were those exhibiting the highest variability in water repellency and the greatest decrease in it with increasing depth (especially in relation to soils under eucalyptus).

Water repellency exhibited significant positive correlation with the $\mathrm{C}$ content and $\mathrm{C} / \mathrm{N}$ ratio of the soils. Soil water repellency was similar in the air-dried samples and field-moist samples.
\end{abstract}

Keywords: Soil water repellency; Forest soils; Soil organic carbon; Soil moisture; NW Spain.

\section{INTRODUCTION}

Water repellency is a natural property of soils which has been identified under a wide range of climatic conditions in many geographic areas (Dekker et al., 2005; Doerr et al., 2000). Soil water repellency (SWR) has traditionally been associated to semi-arid regions; in the last two decades, however, it has also been encountered in wet regions (e.g., Benito et al., 2016; Doerr et al., 2006; Jaramillo et al., 2000; Johnson et al., 2005; Rodríguez-Alleres et al., 2007). Repellency is largely found in sandy soils but has also been observed in silty and clayey soils, peat and even volcanic ash (Jaramillo et al., 2000; MataixSolera and Doerr, 2004; Ritsema et al., 1997; Wallis and Horne, 1992), which suggests that, however slight, SWR is more widespread than initially assumed (de Jonge et al., 2009).

Although the specific substances inducing water repellency in soil remain unknown, its severity has been related to the type of organic matter present in the soil. Also, the phenomenon is known to result from the accumulation of hydrophobic organic acids in root exudates, the formation of fungally and microbially produced compounds or even the direct decomposition of organic matter in soil (Doerr et al., 2000; Goebel et al., 2011). The originating compounds deposit onto mineral surfaces and/or soil aggregates, or form interstitial organic matter (Doerr et al., 2000; Franco et al., 2000). As a result, SWR is restricted to the top few centimetres or decimetres of soil and is usually highly variable in spatial and temporal terms. In fact, SWR peaks in dry periods and diminishes or even disappears altogether in wet periods (e.g. Benito et al., 2016; RodríguezAlleres and Benito, 2011; Santos et al., 2013). Therefore, SWR depends on soil moisture, but also on other factors such as temperature, relative humidity and evapotranspiration rate (Benito et al., 2016; Doerr et al., 2000; Goebel et al., 2011). Water repellency is also influenced by soil $\mathrm{pH}$; thus, it is usually more severe in acid soils than in alkaline soils, which has been ascribed to increased fungal activity and decreased humification of organic matter in the more acid soils (Mataix-Solera et al., 2007; Rodríguez-Alleres et al., 2007; Zavala et al., 2009).
High SWR levels are typically associated to perennial plant species producing substantial amounts of resins, wax or aromatic oils such as pine and eucalyptus trees (Badía et al., 2013; Doerr et al., 2005, 2007; Mao et al., 2016; Rodríguez-Alleres and Benito, 2011; Rodríguez-Alleres et al., 2007).

Galicia (NW Spain) is a region of the European temperatehumid zone where $63 \%$ of the land is occupied by forests (CMR, 2009). The prevailing climax vegetation is the Atlantic oak grove and the dominant species Quercus robur. Repeated deforestation and repopulation have led to this vegetation accounting for only $10 \%$ of the plant cover in oceanic Spain, however. Thus, vast expanses of land in NW Spain were planted with two tree species in order to boost the wood-related industry (wood, pulp and paper) in the XX century, namely: Pinus pinaster and Eucalyptus globulus, which currently occupy $23 \%$ and $19 \%$, respectively, of the land surface in the region (CMR, 2009).

Water repellency is a common feature of surface soils with different textures under the relatively dry conditions of $\mathrm{NW}$ Spain. The prevailing vegetation plays a crucial role in the development and persistence of repellency in soils. It is especially influential on forest soils under $P$. pinaster and E. globu$l u s$, and also, to a lesser extent, on soils under grassland and crops. Coarse-textured soils are known to exhibit more persistent repellency and be repellent at greater depths than finetextured soils (Rodríguez-Alleres et al., 2007, 2012). However, virtually nothing is known about the occurrence and severity of water repellency under $Q$. robur natural woods. This led us to compare SWR and its severity in soils under $Q$. robur natural forests and under $P$. pinaster and E. globulus plantations in the northwest of the Iberian Peninsula. The specific objectives of this work were as follows: $(a)$ to assess the severity of water repellency in samples from the surface of coarse-textured soil under the three most typical plant species of the region (oak, pine and eucalyptus); $(b)$ to examine the variation of water repellency with soil depth and relate it to soil moisture and organic carbon contents; and (c) to compare water repellency between field-moist and air-dried samples. 


\section{MATERIAL AND METHODS Study area}

The study area was located in the province of Pontevedra (southwest of Galicia, NW Spain), which lies in the temperatehumid Atlantic European zone. The oceanic climate of NW Spain features high annual precipitation (ca. $1400 \mathrm{~mm}$ ) that peaks in autumn-winter and is much lower in summer. The temperatures are typical of temperate areas and the annual mean is $8-15^{\circ} \mathrm{C}$.

The study was conducted in 30 zones representing the main types of woodland present in the area, namely: 10 zones of $Q$. robur mature forest, 10 of E. globulus plantations and another 10 of $P$. pinaster plantations. The soils were either Cambisols or Umbrisols (WRB, 2006) and developed on granite, gneiss or quartz schists. The lithological and climatic features of the area have favoured the development of coarse-textured acid soils with high organic matter contents.

\section{Methods}

After litter removal, a representative sample from the top $5 \mathrm{~cm}$ of the A horizon was obtained as a composite of subsamples collected at randomly selected sites in each of 30 study zones. Fifteen of the zones were subjected to additional sampling at $5-10 \mathrm{~cm}, 10-20 \mathrm{~cm}$ and $20-40 \mathrm{~cm}$. All samples were collected at the end of the summer period in order to ensure maximum severity in water repellency (Rodriguez-Alleres and Benito, 2012; Rodríguez-Alleres et al., 2007).

The persistence of water repellency in the samples was determined with the water drop penetration test (WDPT, Van't Woudt, 1959). The test involves dropping distilled water over each soil sample and measuring the time it takes to penetrate it. An amount of about $5 \mathrm{~g}$ of each soil sample was placed in triplicate in Petri dishes of $70 \mathrm{~mm}$ diameter and supplied with five water drops each. A repellency class for each sample was established from the median of 15 measurements, namely: class 0 (non-repellent, WDPT $<5 \mathrm{~s}$ ), class 1 (slightly repellent, $\mathrm{WDPT}=5-60 \mathrm{~s}$ ), class 2 (strongly repellent, WDPT = 60-600 s), class 3 (severely repellent, WDPT $=600-3600 \mathrm{~s}$ ), class 4 (extremely repellent, WDPT $=1-3 \mathrm{~h}$ ), class 5 (extremely repellent, WDPT $=3-6 \mathrm{~h}$ ) and class 6 (extremely repellent, WDPT $>6$ h) (Dekker et al., 2001). Repellency was measured on field-moist samples immediately after recording of their wet weights and also on samples dried at $25^{\circ} \mathrm{C}$ in the air.

Soil moisture content was determined gravimetrically. Particle-size distribution was determined after oxidizing the organic matter with $\mathrm{H}_{2} \mathrm{O}_{2}$, when sieving the sand fractions and using the pipette method to separate silt $(50-2 \mu \mathrm{m})$ from clay $(<2 \mu \mathrm{m})$ fractions (USDA, 2004). Soil acidity $(\mathrm{pH})$ was determined in
1:2.5 soil:water extracts. Total $\mathrm{C}$ and $\mathrm{N}$ were determined with an elemental analyser. By virtue of the absence of carbonates in the acid soils of the area, total carbon values coincided with organic carbon contents (de Blas et al., 2010). All samples were analysed in triplicate and their mean results taken.

All statistical analyses were performed with the software SPSS v. 17.0. Determinations included correlations (Spearman rank correlation coefficient) and analysis of variance (KruskalWallis ANOVA). Because WDPT was measured in ranked categories rather than as numeric values, the tests were of the non-parametric type.

\section{RESULTS}

Table 1 summarizes the properties of the surface soil samples. All soils had sandy loam texture, and sand and clay contents over the ranges $42-75 \%$ and $11-26 \%$, respectively, with no substantial differences among plant covers. Carbon and nitrogen contents were high in all soils and not significantly different among them. However, the average $\mathrm{C} / \mathrm{N}$ ratio differed significantly and was lower $(\mathrm{C} / \mathrm{N}=16)$ under oak than under pine or eucalyptus $(\mathrm{C} / \mathrm{N}=20)$, which suggests more marked mineralization of organic matter under oak cover. Soil moisture contents were significantly higher under oak $(32.4 \pm 5.8 \%)$ than under pine $(20.2 \pm 10.1 \%)$ and eucalyptus $(21.4 \pm 4.1 \%)$, the latter two not differing significantly in this respect.

Figure 1 shows the relative frequencies of median WDPT classes for the field-moist soil samples $\left(\mathrm{WDPT}_{\mathrm{f}}\right)$ and those dried at $25^{\circ} \mathrm{C}\left(\mathrm{WDPT}_{25}\right)$ taken at a depth of $0-5 \mathrm{~cm}$. All $\mathrm{WDPT}_{\mathrm{f}}$ values were very high, with penetration times ranging from 600 $\mathrm{s}$ to more than $6 \mathrm{~h}$ in the soils under oak, $1 \mathrm{~h}$ to more than $6 \mathrm{~h}$ under pine and more than $6 \mathrm{~h}$ under eucalyptus. The ManWhitney test revealed no significant differences in $\mathrm{WDPT}_{\mathrm{f}}$ among plant species, however. Drying at $25^{\circ} \mathrm{C}$ increased water repellency in the soils under oak and made them extremely water repellent (WDPT values from $1 \mathrm{~h}$ to more than $6 \mathrm{~h}$ ). Also, all air-dried samples of soil under pine or eucalyptus were extremely repellent (WDPT $>6 \mathrm{~h}$ ). The Wilcoxon test revealed no significant differences between $\mathrm{WDPT}_{\mathrm{f}}$ and $\mathrm{WDPT}_{25}$ for any type of plant species. Twenty two of the 30 soils retained their repellency class after drying; however, drying increased repellency by 1-3 classes in 5 samples, and decreased it by 1-2 classes in 3.

As can be seen from Figure 2, the persistence of water repellency in the deeper soil layers did differ among tree covers, the soils under eucalyptus exhibiting repellency at the greatest depths. In fact, all soils under eucalyptus were repellent down to $40 \mathrm{~cm}$ and extremely repellent (WDPT $>6 \mathrm{~h}$ ) from 0 to 20 $\mathrm{cm}$. The soil layer from 20 to $40 \mathrm{~cm}$ was less repellent; thus, $40 \%$ of the samples were extremely repellent (WPDT $1-3 \mathrm{~h}$ ), $40 \%$ severely repellent and $20 \%$ moderately repellent.

Table 1. Mean and standard deviation of selected properties of samples collected from the topmost layer $(0-5 \mathrm{~cm})$ of soils under different tree species. $\mathrm{N}=10$ in all cases.

\begin{tabular}{lccc}
\hline & Oak & Pine & Eucalyptus \\
\hline Sand (\%) & $56.1 \pm 7.8 \mathrm{a}$ & $25.0 \pm 5.8 \mathrm{a}$ & $19.0 \pm 3.6 \mathrm{a}$ \\
Silt (\%) & $62.6 \pm 6.9 \mathrm{a}$ & $21.5 \pm 5.0 \mathrm{a}$ & $15.9 \pm 4.3 \mathrm{a}$ \\
Clay (\%) & $63.5 \pm 8.9 \mathrm{a}$ & $20.9 \pm 6.1 \mathrm{a}$ & $15.6 \pm 3.9 \mathrm{a}$ \\
Soil moisture (\%) & $32.4 \pm 5.8 \mathrm{~b}$ & $20.2 \pm 10.1 \mathrm{a}$ & $21.4 \pm 4.1 \mathrm{a}$ \\
$\mathrm{pH}$ & $4.1 \pm 0.2 \mathrm{a}$ & $4.2 \pm 0.4 \mathrm{a}$ & $4.2 \pm 0.3 \mathrm{a}$ \\
$\mathrm{C}\left(\mathrm{g} \mathrm{kg}^{-1}\right)$ & $124.5 \pm 35.9 \mathrm{a}$ & $108.8 \pm 32.6 \mathrm{a}$ & $106.6 \pm 22.5 \mathrm{a}$ \\
$\mathrm{N}\left(\mathrm{g} \mathrm{kg}^{-1}\right)$ & $7.7 \pm 1.7 \mathrm{~b}$ & $5.8 \pm 2.6 \mathrm{ab}$ & $5.7 \pm 1.9 \mathrm{a}$ \\
$\mathrm{C} / \mathrm{N}$ & $16 \pm 2 \mathrm{~b}$ & $21 \pm 6 \mathrm{a}$ & $20 \pm 5 \mathrm{a}$ \\
\hline
\end{tabular}

Within-a-row means followed by the same letter are not significantly different $(\mathrm{p} \leq 0.05)$ 


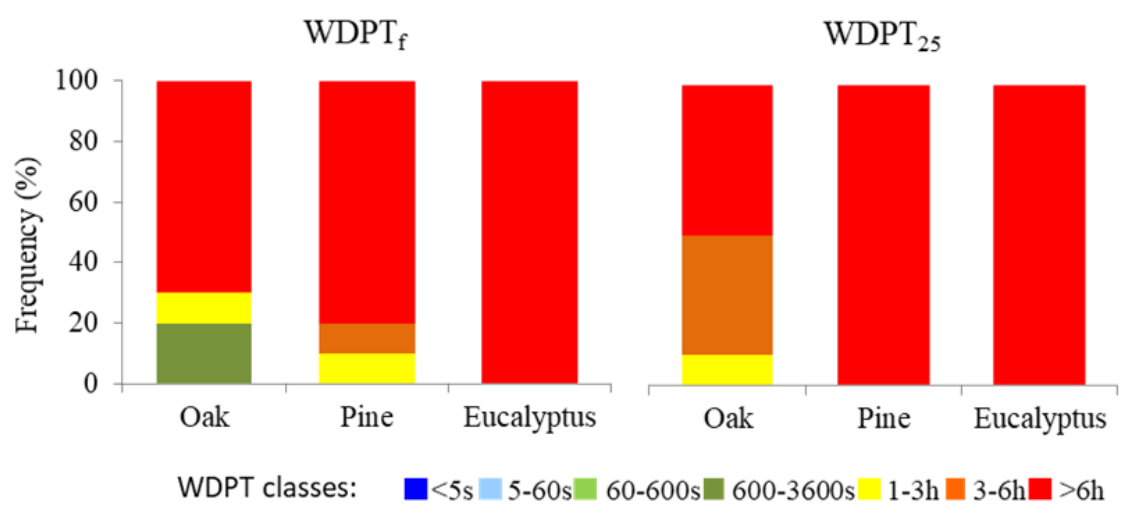

Fig. 1. Relative frequency of median WPDT classes in field-moist $\left(\mathrm{WDPT}_{\mathrm{f}}\right)$ and air-dried $\left(\mathrm{WDPT}_{25}\right)$ surface samples of soils under the three tree species.

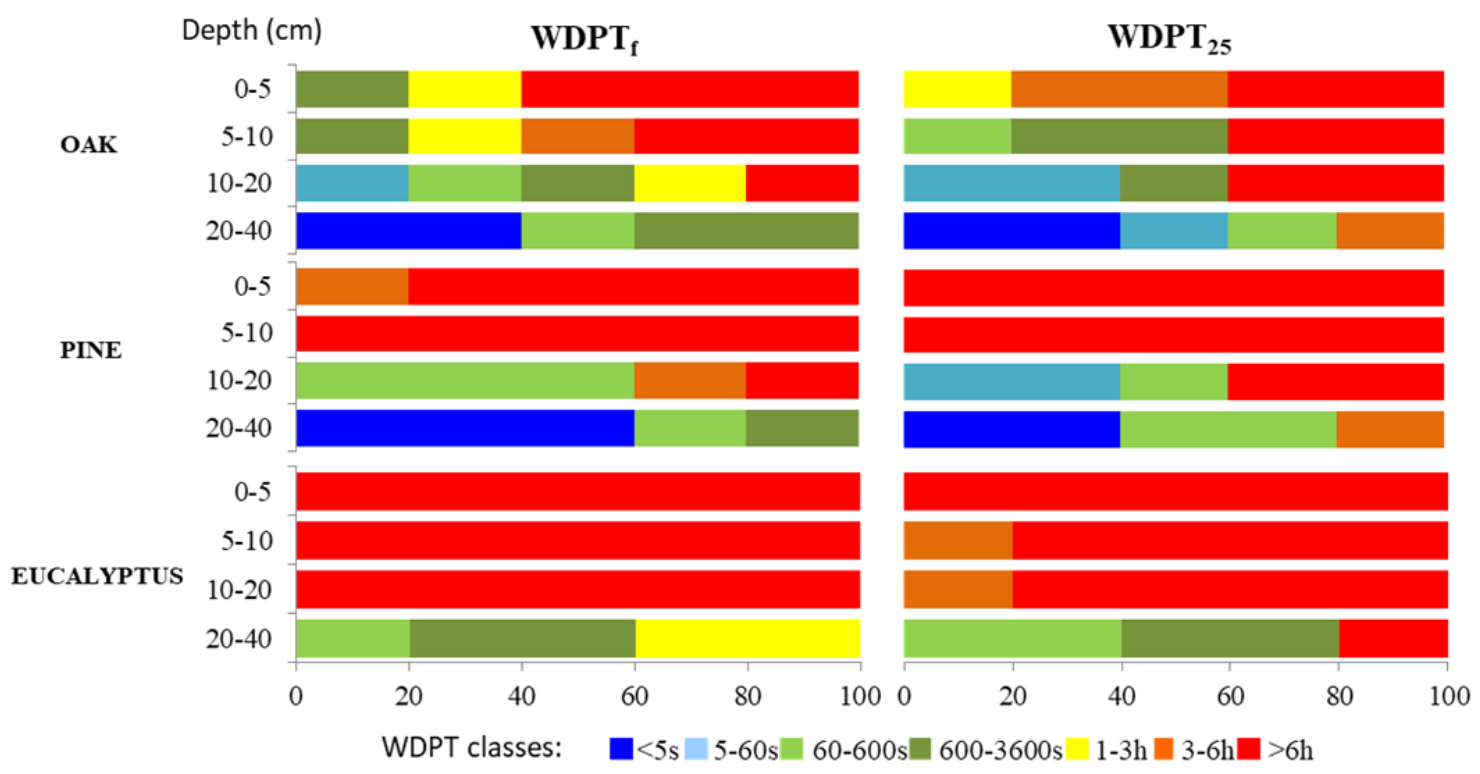

Fig. 2. Relative frequency of median WDPT classes in field-moist $\left(\mathrm{WDPT}_{\mathrm{f}}\right)$ and air-dried samples $\left(\mathrm{WDPT}_{25}\right)$ at different depths of soils under the three tree species.

Table 2. Mean and standard deviation of moisture, $\mathrm{C}$ and $\mathrm{N}$ contents, and $\mathrm{C} / \mathrm{N}$ ratio, of samples obtained at different depths in soils under three different tree species. $\mathrm{N}=5$ in all cases.

\begin{tabular}{lccccc}
\hline & $\begin{array}{c}\text { Depth } \\
(\mathrm{cm})\end{array}$ & $\begin{array}{c}\text { Soil moisture } \\
(\%)\end{array}$ & $\begin{array}{c}\mathrm{N} \\
\left(\mathrm{g} \mathrm{kg}^{-1}\right)\end{array}$ & $\begin{array}{c}\mathrm{C} \\
\left(\mathrm{g} \mathrm{kg}^{-1}\right)\end{array}$ & $\mathrm{C} / \mathrm{N}$ \\
\hline \multirow{4}{*}{ Oak } & $0-5$ & $30.3 \pm 7.1 \mathrm{a}$ & $7.0 \pm 1.3 \mathrm{a}$ & $99.6 \pm 19.0 \mathrm{a}$ & $14 \pm 1 \mathrm{ab}$ \\
& $5-10$ & $22.5 \pm 6.6 \mathrm{a}$ & $6.2 \pm 2,0 \mathrm{a}$ & $85.1 \pm 29.8 \mathrm{a}$ & $14 \pm 1 \mathrm{ab}$ \\
& $10-20$ & $19.3 \pm 8.8 \mathrm{a}$ & $4.5 \pm 3.1 \mathrm{a}$ & $75.8 \pm 61.8 \mathrm{a}$ & $16 \pm 3 \mathrm{ab}$ \\
& $20-40$ & $18.5 \pm 10.5 \mathrm{a}$ & $3.5 \pm 2.9 \mathrm{a}$ & $42.2 \pm 39.7 \mathrm{a}$ & $12 \pm 3 \mathrm{c}$ \\
\hline \multirow{4}{*}{ Pine } & $0-5$ & $17.8 \pm 2.3 \mathrm{a}$ & $4.1 \pm 0.8 \mathrm{a}$ & $87.9 \pm 10.1 \mathrm{a}$ & $22 \pm 5 \mathrm{a}$ \\
& $5-10$ & $16.1 \pm 8.3 \mathrm{a}$ & $3.5 \pm 1.5 \mathrm{a}$ & $64.6 \pm 25.6 \mathrm{a}$ & $19 \pm 2 \mathrm{a}$ \\
& $10-20$ & $17.4 \pm 8.9 \mathrm{a}$ & $3.3 \pm 1.4 \mathrm{a}$ & $57.1 \pm 27.2 \mathrm{a}$ & $18 \pm 3 \mathrm{a}$ \\
\hline \multirow{4}{*}{ Eucalyptus } & $20-40$ & $18.1 \pm 10.8 \mathrm{a}$ & $3.7 \pm 1.7 \mathrm{a}$ & $64.8 \pm 31.7 \mathrm{a}$ & $18 \pm 3 \mathrm{a}$ \\
& $0-5$ & $23.0 \pm 4.6 \mathrm{a}$ & $5.0 \pm 1.3 \mathrm{a}$ & $111.7 \pm 25.3 \mathrm{ab}$ & $22 \pm 3 \mathrm{a}$ \\
& $5-10$ & $18.1 \pm 4.3 \mathrm{a}$ & $4.1 \pm 1.7 \mathrm{a}$ & $78.5 \pm 23.8 \mathrm{ab}$ & $20 \pm 2 \mathrm{a}$ \\
& $10-20$ & $18.6 \pm 7.0 \mathrm{a}$ & $3.6 \pm 1.7 \mathrm{a}$ & $61.9 \pm 20.8 \mathrm{bc}$ & $18 \pm 3 \mathrm{a}$ \\
& $20-40$ & $18.1 \pm 6.5 \mathrm{a}$ & $3.5 \pm 1.3 \mathrm{a}$ & $59.2 \pm 18.3 \mathrm{bc}$ & $18 \pm 3 \mathrm{a}$ \\
\hline
\end{tabular}

Within-a-column means followed by the same letter are not significantly different $(\mathrm{p} \leq 0.05)$

The soils under pine forest were extremely repellent only in the top $10 \mathrm{~cm}$, below which repellency decreased with increasing depth and $60 \%$ of the samples from the $20-40 \mathrm{~cm}$ layer were non-repellent. The soils under oak exhibited a similar repellency pattern, the proportion of extremely repellent sam- ples decreasing with increasing depth (from $80 \%$ with WPDT $>$ $1 \mathrm{~h}$ in the $0-10 \mathrm{~cm}$ layer to $40 \%$ in the $10-20 \mathrm{~cm}$ layer). Below $20 \mathrm{~cm}, 40 \%$ of the samples of soil under oak were non-repellent whereas $40 \%$ were severely repellent and 20\% moderately repellent. The only significant differences as revealed by the 
Man-Whitney test were those between the soils under oak and eucalyptus.

Drying the samples at $25^{\circ} \mathrm{C}$ caused no significant changes in water repellency, the Spearman correlation coefficient for $\mathrm{WDPT}_{\mathrm{f}}$ and $\mathrm{WDPT}_{25}$ being $0.87(p<0.01)$.

Table 2 shows the differences in moisture, $\mathrm{C}, \mathrm{N}$ and $\mathrm{C} / \mathrm{N}$ among samples obtained at different depths in soils under the three different tree covers.

The moisture content exhibited no significant differences at any depth among forest types despite the fact that the soils under oak were slightly moister in the top $10 \mathrm{~cm}$ than were those under pine or eucalyptus.

Overall, C contents decreased with increasing depth in most samples. However, the decrease was only significant between the topmost layer $(0-5 \mathrm{~cm})$ and the deeper ones $(10-20 \mathrm{~cm}$ and $20-40 \mathrm{~cm}$ ), and only under oak. The $\mathrm{C} / \mathrm{N}$ ratio changed little with depth in the soils under pine or eucalyptus, the soils under oak having much lower ratios than those under pine or eucalyptus.

Finally, the $\mathrm{C}$ content exhibited significant positive correlation with the median $\mathrm{WDPT}_{\mathrm{f}}(r h o=0.40, p<0.01)$ and $\mathrm{WDPT}_{25}$ classes $(r h o=0.34, p<0.01)$. The correlation coefficients between the $\mathrm{C} / \mathrm{N}$ ratio and the median WDPTc and $\mathrm{WDPT}_{25}$ classes were 0.49 and $0.54(p<0.01)$, respectively. No significant correlation with moisture or $\mathrm{N}$ content was observed, however.

\section{DISCUSSION}

As in previous studies, the results confirm that water repellency is a widespread phenomenon in coarse-textured forest soils in the NW of the Iberian Peninsula. Also, they confirm that soils under eucalyptus exhibit the highest severity of water repellency in the deeper layers (Rodríguez-Alleres and Benito, 2011, 2012; Rodríguez-Alleres et al., 2007).

Surface soils under eucalyptus and pine forests have also been associated to high levels of water repellency in Portugal (Doerr et al., 1996, 1998; Keizer et al., 2005 a, b; LeightonBoyce et al., 2005, 2007; Santos et al., 2013; Shakesby et al., 1993), South Africa (Scott, 2000), Australia (Crockford et al., 1991; Doerr et al., 2006), Germany (Buczko et al., 2005, 2007), Italy (Alagna et al., 2017), UK (Doerr et al., 2006), USA (Doerr et al., 2009) and SW Spain (Zavala et al., 2009, 2014). Usually, soil water repellency under oak forest is less persistent than it is under pine or eucalyptus forest (Alanis et al., 2017; Zavala et al., 2009, 2014). However, Jiménez-Morillo et al. (2016) found an increased persistence in soils under oak relative to pine in SW Spain and ascribed this result to the increased content in organic matter of the former (especially in the form of organic films coating the finer soil particles).

The high persistence of water repellency in the surface layers of the soils under the three types of tree cover can be ascribed to a combination of factors including the temperatehumid climate of the area, which facilitates biomass production and as a result of which the soils contain increased amounts of organic matter and hydrophobic substances (Rodríguez-Alleres et al., 2007). Also, the high acidity of the soils boosts fungal proliferation in the biomass it contains and delays mineralization of organic matter by forming humus of the mor or acid mull type (Franco et al., 2003; Rodríguez-Alleres et al., 2012). Also, the coarse texture of the soils increases their water repellency by reducing their specific surface area (Rodríguez-Alleres et al., 2007, 2012). In addition, forest soils under pine and eucalyptus trees contain substantial amounts of resins, wax and aromatic oils that increase the severity of water repellency.
De Blas et al. (2010) found evidence that SWR under these tree covers is governed mainly by the concentration of free lipids in hydrophobic coatings. Also, they found the proportions of humic substances and free particulate soil organic matter (SOM) to influence the extent of SWR, the effect depending on the particular type of vegetation. In a subsequent study de Blas et al. (2013) found the free lipid fraction of soils under eucalyptus and pine to consist mainly of sesquiterpenes and diterpenes, respectively; also, they concluded that the major compounds associated to soil water repellency are typically present in higher plants and cannot be synthesized by microorganisms.

The fact that soil water repellency in Spanish forest areas with calcareous soils and a semi-arid climate is typically very low relative to acid forest soils (Arcenegui et al., 2007; Cerdà and Doerr, 2007; Jimenez-Pinilla et al., 2016; Mataix-Solera et al., 2007) has been ascribed to decreased biomass production and the resulting decreased supply of hydrophobic substances to the soil under a dry climate (Jaramillo et al., 2000; MataixSolera and Doerr, 2004; Rodríguez-Alleres et al., 2012). Also, the alkalinity of the soils $\left(\mathrm{pH}_{\mathrm{H} 2 \mathrm{O}}<7\right)$ facilitates dissolution of hydrophobic substances and reduces fungal activity (MataixSolera and Doerr, 2004; Mataix-Solera et al., 2007).

Few studies have reported so high persistence in water repellency with soil depth as found in this work. Walden et al. (2015) found reforestation with E. globulus to induce water repellency across a range of sites in the southwest of Western Australia; contrary to our results, however, they also found SWR to decrease rapidly with increasing depth.

Doerr et al. (2006) examined water repellency in soils differing in texture, organic matter content, moisture and management regime at variable depths and concluded that the last two were reliable predictors for SWR. Also, Vogelmann et al. (2013) concluded that SWR and its persistence in hydrophobic soils decreases with increasing depth and moisture but decreasing organic carbon content. In this work, SWR was positively correlated in a significant manner with the organic $\mathrm{C}$ content of the soils, but not with their moisture content. Our results are consistent with those of Mao et al. (2016), Harper et al. (2000), and Zavala et al. (2009), who also found a significant relationship between SOM and SWR, and confirmed earlier findings of our group (Rodríguez-Alleres and Benito, 2011; Varela et al., 2005). On the other hand, Dekker and Ritsema (1994), and Doerr et al. (2005), found no significant correlation between organic $\mathrm{C}$ and SWR in sandy soils, possibly because although organic $\mathrm{C}$ is a quantitative measure of SOM abundance, SWR persistence is more strongly governed by the composition and quality of organic $\mathrm{C}$ in the soil (Cosentino et al., 2010; Zhang et al., 2004). In fact, our results revealed a significant positive correlation between SWR and the $\mathrm{C} / \mathrm{N}$ ratio that was stronger than that with the content in organic $\mathrm{C}$. The decreased $\mathrm{C} / \mathrm{N}$ ratio of the soils under oak forest suggests stronger decomposition of organic matter and the presence of more evolved humus relative to the soils under pine and eucalyptus. This may account for the decreased severity of water repellency in the soils under oak relative to eucalyptus and hence for the more marked accumulation of organic matter (organic $\mathrm{C}$ and $\mathrm{N}$ compounds) under eucalyptus resulting from less marked mineralization of low-quality organic residues.

According to Goebel et al. (2011), persistent water repellency can hinder the decomposition of SOM and temporarily increase the carbon sink strength of the soil. In long term, however, the reduced water availability will also reduce plant productivity and induce changes in plant composition, thereby potentially offsetting the positive effects of an increased SWR on carbon sequestration in the short term. 
Our results suggest that the extreme water repellency of the humic horizon of coarse-textured soils under dry conditions in NW Spain (especially under E. globulus) can alter their hydrological properties, moisture patterns and water reserves. Properly understanding these consequences is very important to optimize management practices for forest soils with a view to preventing floods, facilitating recharging of underground water and preventing erosion, among others (Benito et al., 2016).

\section{CONCLUSIONS}

Water repellency is a widespread property of coarse-textured forest soils in the northwest of the Iberian Peninsula. All samples from the $0-5 \mathrm{~cm}$ layer under the three types of plant cover exhibited severe to extreme SWR. Water repellency in the soils under Quercus robur natural forest decreased more markedly with increasing depth, especially in relation to the soils under eucalyptus plantation, which were extremely repellent down to $20 \mathrm{~cm}$. Water repellency and its severity increased in the following sequence of forest species: $Q$. robur $<P$. pinaster $<E$. globulus. The differences in water repellency among the soils under different types of vegetation can be ascribed to differences in carbon content and, especially, in $\mathrm{C} / \mathrm{N}$ ratio.

There were no appreciable differences in water repellency between field-moist and air-dried samples. This result confirms previous recommendations that soils should be sampled at the end of the summer period in order to accurately estimate their potential maximum repellency (Rodríguez-Alleres and Benito, 2012; Rodríguez-Alleres et al., 2007).

Acknowledgements. This study was supported by the Ministerio de Ciencia e Innovación (project AGL2008-01399/FOR).

\section{REFERENCES}

Alagna, V., Iovino, M., Bagarello, V., Mataix-Solera, J., Lichner, L., 2017. Application of minidisk infiltrometer to estimate water repellency in Mediterranean pine forest soils. J. Hydrol. Hydromech., 65, 254-263.

Alanís, N., Hernández-Madrigal, V.M., Cerdà, A., Zavala, L.M., Jordán, A., 2017. Spatial gradients of intensity and persistence of soil water repellency under different forest types in Central México. Land Degrad. Develop., 28, $317-$ 327.

Arcenegui, V., Mataix-Solera, J., Guerrero, C., Zornoza, R., Mayoral, A.M., Morales J., 2007. Factors controlling the water repellency induced by fire in calcareous Mediterranean forest soils. European Journal of Soil Science, 58, 12541259.

Badía, D., Aguirre, J.A., Martí, C., Márquez, M.A., 2013. Sieving effect on the intensity and persistence of water repellency at different soil depthts and soil types from NE-Spain. Catena, 108, 44-49.

Benito, E., Rodríguez-Alleres, M., Varela, E., 2016. Environmental factors governing soil water repellency dynamics in a Pinus pinaster plantation in NW Spain. Land Degrad. Develop., 27, 3, 719-728.

Buczko, U., Bens, O., Hüttl, R.F., 2005. Variability of soil water repellency in sandy forest soils with different stand structure under Scots pine (Pinus sylvestris) and beech (Fagus sylvatica). Geoderma, 126, 317-336.

Buczko, U., Bens, O., Hüttl, R.F., 2007. Changes in soil water repellency in a pine -beech forest transformation chronosequence: influence of antecedent rainfall and air temperatures. Ecological Engineering, 31, 154-164.
Cerdà, A., Doerr, S.H., 2007. Soil wettability, runoff and erodibility of major dry-Mediterranean land use types on calcareous soils. Hydrol. Process., 21, 2325-2336.

CMR, 2009. Anuario de estatistica agraria 2009. Conselleria de Medio Rural. Xunta de Galicia.

Cosentino, D., Hallett, P.D., Michel, J.C., Chenu, C., 2010. Do different methods for measuring the hydrophobicity of soil aggregates give the same trends in soil amended with residue? Geoderma, 159, 221-227.

Crockford, S., Topalidis, S., Richardson, D.P., 1991. Water repellency in a dry sclerophyll forest - measurements and processes. Hydrol. Process., 5, 405-420.

de Blas, E., Rodríguez-Alleres, M., Almendros, G., 2010. Speciation of lipid and humic fractions in soils under pine and eucaliptus forest in northwest Spain and its effect on water repellency. Geoderma, 155, 242-248.

de Blas, E., Almendros, G., Sanz, J., 2013. Molecular characterization of lipid fractions from extremely water-repellent pine and euclyptus forest soils- Geoderma, 206, 75-84.

De Jonge, L.W., Moldrup, P., Schjonning, P., 2009. Soil infrastructure, interfaces and translocation processes in inner space ('soil-it-is'): towards a road map for the constraints and crossroads of soil architecture and biophysical processes. Hydrology and Earth System Sciences, 13, 1485-1502.

Dekker, L.W., Ritsema, C.J., 1994. How water moves in a water repellent sandy soil. 1 . Potential and actual water repellency. Water Resources Research, 30, 2507-2517.

Dekker, L.K., Doerr, S.H., Oostindie, K., Ziogas, A.K., Ritsema, C.J., 2001. Water repellency and critical soil water content in a dune sand. Soil Sci. Soc. Am. J., 65, 1667-1674.

Dekker, L.W., Oostindie, K., Ritsema, C.J., 2005. Exponential increase of publications related to soil water repellency. Aust. J. Soil Res., 43, 403-441.

Doerr, S.H., Shakesby, R.A., Wals, R.P.D., 1996. Soil hydrophobicity variations with depth and particle size fraction in burned and unburned Eucalyptus globulus and Pinus pinaster forest terrain in the Agueda basin, Portugal. Catena, 27, 25-47.

Doerr, S.H., Shakesby, R.A., Walsh, R.P.D., 1998. Spatial variability of soil water repellency in fire-prone eucalyptus and pine forest, Portugal. Soil Science, 163, 313-324.

Doerr, S.H., Shakesby, R.A., Walsh, R.P.D., 2000. Soil water repellency: its causes, characteristics and hydrogeomorphological consequences. Earth-Science Reviews, $51,33-65$.

Doerr, S.H., Douglas, P., Evans, R.C., Morley, C.P, Mullinger, N.J., Bryant, R., Shakesby, R.A., 2005. Effects of heating and post-heating equilibration times on soil water repellency. Aust. J. Soil Res., 43, 261-267.

Doerr, S.H., Shakesby, R.A., Dekker, L.W., Ritsema, C.J., 2006. Occurrence, prediction and hydrological effects of water repellency amongst major soils and land use types in a humid temperate climate. Eur. J. Soil Sci., 57, 741-754.

Doerr, S.H., Scott, D.F., Dekker, L.W., Ritsema, C.J., Carter, D., 2007. Water repellence of soils: new insights and emerging research needs. Hydrol. Process., 21, 2223-2228.

Doerr, S.H., Woods, S.W., Martin, D.A., Casimiro, M., 2009. Natural background soil water repellency in conifer forests of the north-western USA: Its prediction and relationship to wildfire occurrence. J. Hydrol., 371, 12-21.

Franco, C.M.M., Clarke, P.J., Tate, M.E., Oades, J.M., 2000. Hydrophobic properties and chemical characterisation of natural water-repellent materials in Australian sands. J. Hydrol., 231-232, 47-58.

Franco, C.M.M., Clarke, P.J., Tate, M.E., Oades, J.M., 2003. Chemical characterisation of water repellent materials in 
Australian sands. In: Ritsema, C.J, Dekker, L.W. (Eds): Soil Water Repellency: Occurrence, Consequences and Amelioration. Elsevier Science, The Netherlands, pp. 37-50.

Goebel, M.-O., Bachmann, J.B.A., Reichstein, M., Janssens, I.A., Guggenberger, G., 2011. Soil water repellency and its implications for organic matter decomposition-is there a link to extreme climatic events? Global Change Biology, 17, 2640-2656.

Harper, R.J., McKissock, I., Gilkes, R.J., Carter, D.J., Blackwell, P.S., 2000. A multivariate framework for interpreting the effects of soil properties, soil management and land use on water repellency. J. Hydrol., 231-232, 371-383.

Jaramillo, D.F., Dekker, L.W., Ritsema, C.J., Hendrickx, J.M.H., 2000. Occurrence of soil water repellency in arid and humid climates. J. Hydrol., 231-232, 105-111.

Jiménez-Morillo, N.T., González-Pérez, J.A., Jordán, A., Zavala, L.M., de la Rosa, J.M., Jiménez-González, M.A., González-Vila, F.J., 2016. Organic matter fractions controlling soil water repellency in sandy soils from the Doñana National Park (SW Spain). Land Degrad. Develop., 27, 5, 1413-1423.

Jimenez-Pinilla, P., Lozano, E., Mataix-Solera, J., Arcenegui, V., Jordán, A., Zavala, L.M., 2016. Temporal changes in soil water repellency after a forest fire in a Mediterranean calcareous soil: influence of ash and different vegetation type. Sci. Total Environ., 572, 1252-1260.

Johnson, M.S., Lehmann, J., Steenhuis, T.S., de Oliveira, L.V., Fernandes, E.C.M., 2005. Spatial and temporal variability of soil water repellency of Amazonian pastures. Aust. J. Soil Res., 43, 319-326.

Keizer, J.J., Coelho, C.O.A., Matías, M.J.S., Domingues, C.S.P., Ferreira, A.D.J., 2005a. Soil water repellency under dry and wet antecedent weather conditions for selected landcover types in the coastal zone of central Portugal. Aust. J. Soil Res., 43, 3, 297-308.

Keizer, J.J., Ferreira, A.J.D., Coelho, C.O.A., Doerr, S.H., Malvar, M.C., Domingues, C.S.P., Perez, I.M.B., Ruiz, C., Ferrari, K., 2005b. The role of tree stem proximity in the spatial variability of soil water repellency in a eucalypt plantation in coastal Portugal. Aust. J. Soil Res., 43, 3, 251-260.

Leighton-Boyce, G., Doerr, S.H., Shakesby, R.A., Walsh, R.P.D., Ferreira, A.D.J., Boulet, A.K., Coelho, C.O.A., 2005. Temporal dynamics of water repellency and soil moisture in eucalypt plantations, Portugal. Aust. J. Soil Res., 43, 3, 269-280.

Leighton-Boyce, G., Doerr, S.H., Shakesby, R.A., Walsh, R.D.P., 2007. Quantifying the impact of soil water repellency on overland flow generation and erosion: a new approach using rainfall simulation and wetting agents on in situ soils. Hydrol Process., 21, 2337-2345.

Mao, J., Nierop, K.G.J., Rietkerk, M., Sinninghe Damsté J.S., Dekker, S.C., 2016. The influence of vegetation on soil water repellency-markers and soil hydrophobicity. Sci. Total Environment, 566-567, 608-620.

Mataix-Solera, J., Doerr, S.H., 2004. Hydrophobicity and aggregate stability in calcareous topsoils from fire-affected pine forests in southeastern Spain. Geoderma, 118, 1-2, 77-88.

Mataix-Solera, J., Arcenegui, V., Guerrero, C., Mayoral, A.M., Morales, J., Gonzalez, J., García-Orenes, F., Gómez, I., 2007. Water repellency under different plant species in a calcareous forest soil in a semiarid Mediterranean environment. Hydrol. Process., 21, 2300-2309.

Ritsema, C.J., Dekker, L.W., Heijs, A.W.J., 1997. Threedimensional, fingered flow patterns in a water repellent sandy field soil. Soil Science, 162, 79-90.
Rodríguez-Alleres, M., Benito, E., de Blas, E., 2007. Extent and persistence of water repellency in north-western Spanish soils. Hydrol. Process., 21, 2291-2299.

Rodríguez-Alleres, M., Benito, E., 2011. Spatial and temporal variability of surface water repellency in sandy loam soils of NW Spain under Pinus pinaster and Eucalyptus globulus plantations. Hydrol. Process., 25, 3649-3658.

Rodríguez-Alleres, M., Benito, E., 2012. Temporal fluctuations of water repellency in forest soils of Galicia, NW Spain. Do soil samples dried at laboratory reflect the potential soil water repellency? Hydrol. Process., 26, 8, 1179-1187.

Rodríguez-Alleres, M., Varela, M.E., Benito, E., 2012. Natural severity of water repellency in pine forest soils from NW Spain and influence of wildfire severity on its persistence. Geoderma, 191, 125-131.

Santos, J.M., Verheijen, F.G.A., Wahren, F.T., Wahren, A., Feger, K.H., Bernard-Jannin, L., Rial-Rivas, M.E., Keizer, J.J., Nunes, J.P., 2013. Soil water repellency dynamics in pine and eucalypt plantations in Portugal-A high resolution time series. Land Degrad. Develop., 27, 5, 1334-1343.

Scott, D.F., 2000. Soil wettability in forested catchments in South Africa as measured by different methods and as affected by vegetation cover and soil characteristics. J. Hydrol., 231-232, 87-104.

Shakesby, R.A., Coelho, C.O.A., Ferreira, A.J.D., Terry, J.R., Walsh, R.P.D., 1993. Wildfire impacts on soil erosion and hydrology in wet Mediterranean forest, Portugal. Int. J. Wildland Fire, 3, 95-110.

USDA, 2004. Soil Survey Laboratory Methods Manual. Soil Survey Investigation report, vol. 42. Version 4.0. USDANCRS, Lincoln, NE.

Van't Woudt, B.D., 1959. Particle coatings affect the wettability of soils. Journal of Geophysical Research, 64, 263-267.

Varela, M.E., Benito, E., de Blas, E., 2005. Impact of wildfires on surface water repellency in soils of NW Spain. Hydrol. Process., 19, 3649-3657.

Vogelmann, E.S., Reichert, J.M., Prevedello, J., Consensa, C.O.B., Oliveira, A.É., Awe, G.O., Mataix-Solera, J., 2013. Threshold water content beyond which hydrophobic soils become hydrophilic: The role of soil texture and organic matter content. Geoderma, 209-210, 177-187.

Walden, L.L., Harper, R.J., Mendham, D.S., Henry, D.J., Fontaine, J.B., 2015. Eucalyptus reforestation induces soil water repellency. Soil Research 53, 168-177.

Wallis, M.G., Horne, D.J., 1992. Soil water repellency. Advances in Soil Science, 20, 91-146.

WRB, 2006. World Reference Base for Soil Resources 2006. World Soil Resources Reports, No 103, FAO, Rome.

Zavala, L.M., González, F.A., Jordán, A., 2009. Fire-induced soil water repellency under different vegetation types along the Atlantic dune coast-line in SW Spain. Catena, 79, 153162.

Zavala, L.M., García-Moreno, J., Gordillo-Rivero, A.J., Jordán, A., Mataix-Solera, J., 2014. Natural soil water repellency in different types of Mediterranean woodlands. Geoderma, 226-227, 170-178.

Zhang, B., Peng, X.H., Zhao, Q.G., Hallett, P.D., 2004. Eluviation of dissolved organic carbon under wetting and drying and its influence on water infiltration in degraded soils restored with vegetation. Eur. J. Soil Sci., 55, 725-737.

Received 23 January 2018 Accepted 23 February 2018 